\title{
The Effect of Financial Literacy and Financial Inclusion on Economic Growth in Indonesia
}

\author{
Nurul Hidayatinnisa', Fauziah $^{2}$, Shinta Maharani Trivena ${ }^{3}$, Yulis Nurul Aini ${ }^{4}$
}

${ }^{1,2,3,4}$ Business Administration Department, State Polytechnic of Malang, Indonesia. Soekarno Hatta Street No.9, Jatimulyo, Lowokwaru, Malang City, East Java 65141

*Corresponding author. Email: nurulnisa@polinema.ac.id

Increasing financial literacy and inclusion become a global issue that are believed affect economic growth. However, in Indonesia, increasing financial literacy and inclusion in several provinces is not followed by the economic growth. The purpose of this research is to analyze the effect of financial literacy and financial inclusion on economic growth in Indonesia. This study analyzed 34 provinces in Indonesia with 2 survey periods, 2016 and 2019. The method of the data analysis used panel data regression with e-views 10 software. Moreover, Chow test and Hausman test are carried out to determine the best model. The results of the hypothesis test showed that financial literacy and financial inclusion have no significant effect on economic growth in Indonesia, neither partially or simultaneously. It showed that the financial literacy and inclusion improvement in Indonesia need to be enhanced in order to achieve inclusive growth as the main goal.

OPEN ACCESS

ISSN 2528-4649 (online)

ISSN 2338-4409 (print)

Reviewed by:

ViolindaVinola HerawatyGalih

Wicaksono,

*Correspondence:

Nurul Hidayatinnisa'

nurulnisa@polinema.ac.id

Received: June 4, 2021

Accepted: August 24, 2021

Published: September 27, 2021

JBMP: Jurnal Bisnis, Manajemen dan

Perbankan.

Vol: $7 /$ No. 2

doi: 10.21070/jbmp.v7vi2.1539
Keywords: Financial Literacy, Financial Inclusion, Economic Growth 


\section{INTRODUCTION}

In the last few decades, increasing financial literacy and inclusion has become a global issue to play an important role in promoting economic growth. According to Otoritas Jasa Keuangan (OJK) (2007), empowering consumers through financial literacy will encourage the achievement of financial system stability, improve people's welfare, reduce poverty and income inequality, as well as achieve more inclusive development. The 7th President of the Republic of Indonesia, Joko Widodo, launched the National Strategy for Indonesian Financial Literacy (SNLKI) on November 19, 2013. The SNKLI is part of the Trilogy of Policy Instruments to increase market confidence and consumer equality as well as financial services industry (level playing field).

Otoritas Jasa Keuangan (2017a), defines financial literacy as knowledge, beliefs and skills possessed by the community that can influence attitudes and behavior of the community in improving the quality of decision making and financial management to achieve public welfare.

Thus, according to the definition, it can be seen that financial service business actors, financial products consumers, and society are expected not only to know and understand financial services, but also to improve their ability to make financial decisions. Moreover, it changes their attitudes in managing finance to enhance the public welfare.

For Indonesian people, financial literacy has become a necessity for living. Therefore, the knowledge of financial literacy becomes life skill which is owned by individual in living his life for a long term. People who have high financial literacy (well literate) will more easily understand things related to financial services industry, including its products, services, and procedural. Also, they will have comprehensive information, so that they can access the products and services of the financial services industry as needed in daily life activities.

People who have high financial literacy (well literate) tend to find it easier to choose and determine financial products or services according to their respective needs and abilities, so that in the end they can improve their welfare. In addition, people who have high financial literacy (well literate) tend to have better financial management skills in supporting their financial well-being. Thus, the creation of a society that is well literate and financially inclusive will ultimately support economic growth.

The Center for Financial Inclusion defines financial inclusion (financially inclusive) as access to financial products or services as needed, including products or services in the form of credits, savings, insurance and payments. Financial inclusion also contains quality access, which includes convenience, affordability and suitability of financial products or services with regard to consumer protection. In addition, the access to these financial products or services is available to everyone.

According to the Indonesian Financial Literacy National
Strategy (SNLKI), a good public financial literacy (well literate) will be followed by public financial inclusion. People who have knowledge and understanding regarding financial service institutions, skills in utilizing financial products and services, also have confidence in financial service institutions must be supported by access availability to financial institutions, financial products and financial services. Indonesian government gives special attention to increase financial inclusion in Indonesia, because national financial inclusion plays an important role in encouraging sustainable national economic growth. In addition, financial inclusion can reduce poverty and income inequality, which in turn can improve people's welfare.

According to Levine (2005), there are four roles of the financial sector that beneficial to the economy i.e., reducing risk, mobilizing savings, reducing transaction and information costs, and encouraging specialization. Through this role, the financial sector able to create capital accumulation and technological innovation to increase economic growth. Financial inclusion can increase savings mobilization, reduce transaction and information costs, increase capital allocation and asset liquidity and encourage specialization, so that can create capital accumulation which further enhances the economic growth. In addition, financial inclusion through increasing the number of credits will encourage investment in activities that have high added value and ultimately accelerate economic growth (Fabya, 2011). By making finance available and reached to all economic agents, it will affect the growth of economic activity which will increase the country's output.

The 2019 National Financial Literacy and Inclusion Survey (SNLIK) conducted by Otoritas Jasa Keuangan illustrates that Indonesia's financial literacy condition still low despite an increase from the 2 previous surveys, namely in 2013 and 2016. Indonesia's financial literacy level has increased from $21,84 \%$ in 2013 , to $29.66 \%$ in 2016 , and increased to $38.03 \%$ in 2019 . The survey results also showed that the financial inclusion index of the Indonesian people has increased from $59.74 \%$ in 2013 to $67.82 \%$ in in 2016 and increased again to $76.19 \%$ in 2019 . However, the increase in financial literacy and inclusion in Indonesia was not accompanied by economic growth. Based on BPS data, economic growth in 2013 reached $5.56 \%$, decreased to $5.03 \%$ in 2016, and declined again to $5.02 \%$ in 2019 .

\section{[Figure 1 about here.]}

Based on Figure 1, it can be seen that the increase in Indonesia's financial literacy and inclusion in 2016 and 2019 was not accompanied by an increase in Indonesia's economic growth. This phenomenon contrast to the objectives of the National Strategy for Financial Literacy in Indonesia (SNLKI) and the National Strategy for Financial Inclusion (SNKI) which target the increasing financial literacy and inclusion to achieve inclusive economic growth.

Therefore, this study will examine the effect of financial literacy and financial inclusion on economic growth in 
Indonesia. The results of this study are expected to be able to add a comprehensive source of reference and insight on financial literacy and financial inclusion and their impact on economic growth. The results of this study are also expected to be one of the government's considerations in making and designing policies and strategies to increase economic growth through financial literacy and inclusion. This study is also an evaluation of whether the efforts that have been made by the government to increase financial literacy and inclusion in Indonesia are in line with the targets to be achieved or still need to add steps to increase financial literacy and inclusion in order to achieve inclusive growth.

\section{LITERATURE REVIEW}

\section{Financial Literacy}

Otoritas Jasa Keuangan (20117a) provides a definition of financial literacy as outlined in Otoritas Jasa Keuangan Regulation Number 76/POJK.07/2016. The regulation explains that financial literacy is the knowledge, belief, and skills possessed by the community that can influence the attitudes and behavior of the community in improving the quality of decision making and the quality of financial management so that can achieve public welfare. Otoritas Jasa Keuangan (2017b) also provides a more detailed definition in the SNLKI (Revisit 2017). The document explains that financial literacy is public knowledge and understanding of the concepts and risks of products or services in the financial services industry, including the skills, motivations and beliefs possessed by the community to apply their knowledge and understanding in effective decision making to improve financial welfare of individuals and communities and can increase community participation in national economic activities.

When Indonesian people do not have adequate financial literacy, every individual in Indonesia cannot choose savings or investment product that is suitable for him/her. Thus, there is high potential for fraud risk. Financial literacy will occur if someone has expertise or ability that makes that person achieve his goals by utilizing existing resources (Widayati, 2010). According to Manurung (2009), financial literacy is a person's ability or knowledge in managing all of his financial resources effectively.

The purpose of financial literacy is to improve the quality of individual financial decision-making and change individual attitudes and behavior in financial management, so that to be able to determine and utilize financial institutions, products and services that are in accordance with needs and abilities of consumers and community to achieve prosperity (Financial Services Authority, 2017).

Based on National Survey of Financial Literacy and Inclusion (SNLIK) in 2013 (Financial Services Authority, 2014), the level of financial literacy of the Indonesian population is divided into four parts, i.e:

1. Well literate: it means that the public has knowledge and confidence about financial service institutions and financial service products. Knowing the features, benefits and risks, as well as rights and obligations related to financial products and services, as well as having skills in using these financial products and services.

2. Sufficient literate: the public has knowledge and confidence about financial service institutions and financial products and services. Knowing features, benefits and risks, as well as rights and obligations related to financial products and services without having skills in using these financial products and services.

3. Less literate: is when people only have knowledge about financial service institutions, financial products and services. They do not know in detail about the features, benefits and risks, as well as rights and obligations related to financial products and services.

4. Not literate, people do not have knowledge and confidence in financial institutions and services as well as financial products and services, as well as do not have skills in using financial products and services.

\section{Financial Inclusion}

The literature on financial inclusion has various concept definitions. Amidžić, Massara, and Mialou (2014) states that financial inclusion is an economic state in which individuals and companies are not denied access to financial services. The Global Financial Development Report (2014) defines financial inclusion as a condition where the majority of individuals can take advantage of available financial services and minimize the presence of groups of individuals who are not aware of the benefits of access to finance through access that is available at affordable costs. According to Bank Indonesia (2014), financial inclusion is all efforts to increase public access to banking services by eliminating all forms of obstacles. Hannig and Jansen (2010) reveals that financial inclusion is an effort to incorporate the unbanked into the formal financial system so that they have the opportunity to enjoy banking services. In addition, according to Sarma (2012) financial inclusion is a process that ensures easy access, availability, and benefits from the formal financial system for all economic actors.

According to Julie (2016) financial inclusion is an intervention strategy that seeks to overcome market frictions to prevent financial markets from operating for the poor or underprivileged. This intervention aims to attract the unbanked population into the formal financial system, so that they have the opportunity to access formal financial services ranging from savings, payments, transfers, credit and insurance. Chakrobarty (2011) says that financial inclusion promotes savings and develops a culture of saving, increases access to credit, both entrepreneurship and consumption and also enables efficient payment mechanisms, thereby strengthening the resource base of financial institutions that are able to provide economic benefits as a resource and the availability of efficient and allocative payment mechanisms. Policymakers are required to create effective opportunities for financial inclusion. Key to such interventions are policies that accelerate the introduction of innovative technologies, regulatory reforms, and infrastructure acquisitions that reduce transaction costs and enable faster, efficient and convenient delivery of financial services to a broad section of the population (Neaime and Gaysse, 2018).

Otoritas Jasa Keuangan (20117a) provides a definition of financial inclusion as outlined in Otoritas Jasa Keuangan 
Regulation Number 76/POJK.07/2016. According to the regulation, financial inclusion defined as the availability of access to various financial institutions, products and services in accordance with the needs and abilities of the community in order to improve the welfare of the community.

The Center for Financial Inclusion also provides a definition of financial inclusion, namely public access to financial products or services that meet community needs. These products or services include credit, savings, insurance and payments. The availability of quality access includes convenience, affordability, suitability with due regard to consumer protection, and its availability is also given to everyone.

According to Bank Indonesia (2014) financial inclusion is the right of everyone to have full access and services from financial institutions on time, convenient, informative, and affordable manner, with full respect for their dignity and worth. Financial services are available to all segments of society, with special attention to the poor, the productive poor, and residents in remote areas (Bank Indonesia, 2014).

\section{Relationship between Financial Literacy, Financial Inclusion and Economic Growth}

Economic growth is an achievement through a process that is supported by various sectors in the economy. One sector that plays an important role in supporting economic growth is the financial sector. According to Levine (2005), there are four roles of the financial sector that are beneficial to the economy, namely reducing risk, mobilizing savings, reducing transaction and information costs, and encouraging specialization. Through this role, the financial sector is able to create capital accumulation and technological innovation so as to increase economic growth. Financial inclusion can increase savings mobilization, reduce transaction and information costs, increase capital allocation and asset liquidity and encourage specialization, so as to create capital accumulation which in turn increases economic growth. In addition, financial inclusion through increasing the number of credits will encourage investment in activities that have high added value and ultimately accelerate economic growth (Fabya, 2011). By making finance available and affordable to all economic agents, it will affect the growth of economic activity which will increase the output of a country.

Several studies examine the relationship between financial inclusion and economic growth. There is substantial evidence in the literature that countries with high financial inclusion indexes tend to achieve high rates of economic growth. Kendall et al. (2010) and Ghosh (2011) evaluate the role of access to finance on economic growth with data at the Indian sub-national level which proves the positive impact of access to financial services and utilization of financial services on economic growth in India. Mihasonirina and Kangni (2011) also found the significance of financial inclusion and communication technology on economic growth. Martinez et al. (2011) argue that access to finance is an important policy tool used by governments and policy makers to stimulate economic growth. By making finance available and affordable to economic agents, it will affect the growth of economic activity which will increase output. Sarma and Pais (2011) found empirical evidence of a relationship between financial inclusion and economic growth using data from 49 countries. Masoud and Hardaker (2012); Demirgüç-Kunt and Klapper, (2012); Falahaty and Hook (2013) show that financial development is a significant determinant of economic growth. These findings indicate that improving the functioning of the banking sector is very important to spur economic growth. Law, Azman-Saini, and Hui (2014) emphasize that a well-developed financial system is essential for economic growth. Then Sarma (2016) continued his research by analyzing the causal relationship between various dimensions of financial inclusion and economic growth, which proves the existence of a two-way causal relationship between access to banking services and economic growth. Recently, Pradhan et al. (2016), Kim et al (2018), Gul et al., (2018), and Raza et al (2019) also prove that there is a significant positive relationship between financial inclusion and economic growth.

The above findings contradict the findings of Naceur and Ghazounai (2007) who examined the relationship between financial development and economic growth for 11 countries in the MENA region (Middle East and North Africa). The empirical results of this study indicate that bank development has a negative effect on economic growth. Khan's (2011) findings also show that financial inclusion has a negative impact on economic growth. Financial inclusion can lower credit standards because financial institutions try to reach the bottom of the poor by lowering loan terms, besides that it can increase bank reputation risk because in order to improve banking service facilities, some countries lower the standard for establishing a financial institution for rural areas, and can cause instability due to inadequate and immature regulations from Microfinance institutions.

\section{METHOD (FOR RESEARCH ARTICLE)}

\section{Object}

The object of this research is 34 provinces in Indonesia, namely Naggroe Aceh Darussalam, North Sumatra, West Sumatra, Riau Islands, Jambi, South Sumatra, Bangka Belitung, Bengkulu, Lampung, DKI Jakarta, West Java, Banten, Central Java, DI Yogyakarta, Java East, Bali, NTB, NTT, North Sulawesi, West Sulawesi, Central Sulawesi, Southeast Sulawesi, South Sulawesi, Gorontalo, North Kalimantan, West Kalimantan, Central Kalimantan, South Kalimantan, East Kalimantan, Maluku, Maluku, West Papua and Papua.

\section{Variables and Operational Definitions}

The independent variables in this study are financial literacy (X1) and financial inclusion (X2). The dependent variable used is economic growth (Y). Operational definitions and indicators or proxies for each variable are described in table 1 .

[Table 1 about here.] 


\section{Research Model}

The research model is presented in Figure 2. There are 3 hypotheses in this study, namely:

$\mathrm{H}$ 1: Financial literacy has a positive and significant effect on economic growth

$\mathrm{H}$ 2: Financial inclusion has a positive and significant effect on economic growth

$\mathrm{H}$ 3:Financial literacy and financial inclusion simultaneously have a positive and significant effect on economic growth

[Figure 2 about here.]

\section{Data and Data Sources}

The type of data used is panel data, which is a combination of cross section data (34 provinces) and time series ( 2 survey periods). The data used in this study is secondary data collected from several sources, namely SNLIK 2016, SNLIK 2019, and BPS.

\section{Data analysis method}

This research is in the form of hypothesis testing which aims to examine the contribution of cost control effectiveness and working capital turnover on economic profitability. The form of data used in the study is in the form of panel data. Panel data is a combination of time series and cross section data. Substantially, panel data is able to overcome the problems caused by neglecting the relevant independent variables (omitted variables). Therefore, to overcome the problem of inter-correlation which ultimately results in inaccurate interpretation of the regression, the panel data regression method is used (Bond, 2002). The data is taken from 14 sample companies which are cross section units and time series data from the period $2012-2016$. The analytical method used in this research is descriptive statistical analysis and panel data regression analysis with the help of the EViews Program (Winarno, 2011). To determine the significance level of each independent variable regression coefficient on the dependent variable, multiple linear regression analysis (multiple regression linear analysis) or also known as Ordinary Least Square is used. Multiple linear regression is a statistical technique used to test the effect of several independent variables on the dependent variable (Sekaran, 2006). The panel regression equation used in this study is:

$$
P E_{i t}=\alpha+\beta_{1} L K_{i t}+\beta_{2} I K_{i t}+e_{i t}
$$

Here, PEit is the Provincial Economic Growth at time t; $\alpha$ is a constant (intercept); $\beta 1, \beta 2$ is the Regression Coefficient; $L K \neg$ it is Provincial Financial Literacy at time t, $\mathrm{IK} \neg$ it is Provincial Financial Inclusion at time t; and e is a disturbing factor (disturbance error)

Common Effect Model (CEM), Fixed Effect Model (FEM), and Random Effect Model (REM) approaches were used in panel data regression analysis (Bond, 2002; Drukker, 2003). Determining which model is the most appropriate to use among the three models consists of several stages, namely: 1) Chow test, conducted to determine whether the Common Effect model is better to use than the Fixed Effect. 2) Hausman test, conducted to determine whether the Fixed Effect model is better to use than the Random Effect.

A good regression model must produce an unbiased linear estimation (Best Linear Unbiased Estimator). The panel data model has the potential for heteroscedasticity and autocorrelation problems. This problem generally occurs because of a combination of two forms of data, namely cross section and time series. Therefore, the classical assumption test consists of heteroscedasticity and autocorrelation tests first. However, if it is known that the random effects model is a suitable model for panel data regression, then the classical assumption test is not relevant to be carried out. Because, random effects are believed to be able to overcome the problem of time series autocorrelation and the correlation between observations (cross section). The method used to estimate the random effect model is known as the Generalized Least Square (GLS) method.

\section{RESULTS AND DISCUSSION}

\section{Descriptive Statistical Analysis}

Descriptive statistical test aims to provide an overview of the object of research. The calculation of descriptive statistics in this study includes the minimum, maximum, average, and standard deviation values of each variable. The dependent variable in this study is economic growth (Y) while the independent variables in this study are financial literacy (X1) and financial inclusion (X2). The statistical distribution for each variable in this study is presented in Table 2.

\section{[Table 2 about here.]}

The final data used in the study were 68 observation results derived from a combination of cross-sectional data of 34 provinces and time series of 2 survey periods, namely 2016 and 2019. Table 3 shows that the highest economic growth rate reached $9.9 \%$, while the minimum reached $15.7 \%$. The high and low levels of economic growth reflect that the ability of a province to produce Gross Domestic Product (GDP) per capita in different observation periods.

\section{Description of Research Variables}

Data on the financial literacy index, financial inclusion index and Indonesia's economic growth in 2016 and 2019 are presented in the Table 3 .

[Table 3 about here.]

\section{Panel Data Regression Selection}

The analysis steps used to determine the best estimation model in the panel data are by estimating the Common Effect (CEM), Fixed Effect (FEM) and Random Effect (REM) 
models. The regression equation used to estimate the model is as follows:

$$
P E_{i t}=\alpha+\beta_{1} L K_{i t}+\beta_{2} I K_{i t}+e_{i t}
$$

The equation is obtained after carrying out a number of testing stages which identified deviations from the classical assumptions. The statistical results obtained in estimating the CEM, FEM, and REM models are presented in the Table 4.

[Table 4 about here.]

The table above shows that the t-statistical and probability values for each model are the basis for selecting the best model in panel data regression. The estimation results explain that each model has a different significance value. Therefore, to find which model is the best, further analysis is carried out using the Chow Test and Hausman Test.

[Table 5 about here.]

The chow test aims to determine which model is better to use between the Common Effect and Fixed Effect models. Based on the table above, the prob value in the Chi-square cross-section is smaller than alpha $(\alpha)(0.0000<0.05)$, so H0 is rejected. This means that the Fixed Effect model is better used than the Common Effect model.

\section{[Table 6 about here.]}

Hausman test aims to determine which model is better between the Fixed Effect model and the Random Effect model. Table 6 shows that the probability value in the random cross-section is greater than alpha $(\alpha)(0.5481>$ $0.05)$, so HO is accepted. Thus, it is concluded that the suitable model used in panel data regression is the Random Effect Model (REM). With the selection of the Random Effect Model (REM), the classical assumption test is irrelevant.

\section{Panel Data Regression Analysis and Hypothesis Testing}

This research was conducted to see the effect of the independent variable on the dependent variable. Panel data regression analysis is used to see whether the hypothesis that has been made will be accepted or rejected. The significance level used is $5 \%$. The estimated statistical model is the best model and is free from deviations from classical assumptions. To find out the results of hypothesis testing from panel data regression analysis, it can be seen in Table 7.

[Table 7 about here.]
Based on the table above, the panel data regression equation is obtained as follows:

$$
P E_{i t}=0.057584-0.000893 L K_{i t}-0.005242 I K_{i t}
$$

The t-statistic test shows how far the influence of one independent variable individually in explaining the dependent variable. The test criteria use a significance rate of 0.05 . If the significance value is $<5 \%$ then $\mathrm{H} 0$ is rejected or $\mathrm{Ha}$ is accepted and if the significance value is $5 \%$ then $\mathrm{H} 0$ is accepted or Ha is rejected. Table 7 shows the results of the significance test between financial literacy and financial inclusion on economic growth. The table shows that neither financial literacy nor financial inclusion has a significant effect on economic growth. This is indicated by the significance value of financial literacy and financial inclusion greater than alpha $(0.9647>0.05 ; 0.7509>0.05)$. Based on these results, it can be concluded that the first hypothesis and the second hypothesis in this study were rejected.

Table 7 also shows the results of the F-Statistics test. The F-statistical test shows how far the influence of the independent variables simultaneously in explaining the dependent variable. The test criteria use a significance rate of 0.05 . If the significance value is $<5 \%$ then $\mathrm{H} 0$ is rejected or $\mathrm{Ha}$ is accepted and if the significance value is $5 \%$ then $\mathrm{H} 0$ is accepted or Ha is rejected. Based on table 7, it is known that the significance value of F-statistics is greater than alpha $(0.901369>0.05)$. Therefore, it can be concluded that the third hypothesis in this study is rejected.

\section{Discussion}

The results of data analysis for the first hypothesis which states that there is an effect of financial literacy on economic growth, it is found that partially financial literacy has no significant effect on economic growth in Indonesia. The results of data analysis for the second hypothesis which states that there is an effect of financial inclusion on economic growth also found that partially financial inclusion has no significant effect on economic growth in Indonesia. Likewise, the results of data analysis for the third hypothesis which states that there is an effect of financial literacy and financial inclusion on economic growth, it is found that simultaneously financial literacy and inclusion have no significant effect on economic growth in Indonesia.

This finding contradicts the research conducted by Kendall et al. (2010), Ghosh (2011), Mihasonirina and Kangni (2011), Martinez et al. (2011), Sarma and Pais (2011), Masoud and Hardaker, 2012; Demirgüç-Kunt and Klapper, 2012; Falahaty and Hook (2013), Law, AzmanSaini, and Hui (2014), Sarma (2016), Pradhan et al. (2016), Gul et al., (2018), Kim et al (2018) and Raza et al (2019) which prove that financial literacy and inclusion have a positive and significant effect on economic growth.

However, this rejected hypothesis can be explained by the phenomenon of the global economy which is keep 
slowing down from 2018 to 2019 which is one of the research periods. The global economic slowdown was caused, among others, by the escalation of the trade war between the United States and China, the decline in global demand, stagnation in world commodity prices, as well as the economic crisis and political tensions in a number of regions.

In the midst of the weakening condition and uncertainty of the global economy throughout 2019, Indonesia was able to demonstrate its economic resilience, as can be seen from Indonesia's ability to maintain economic growth in the range of $5 \%$, namely by growing at $5.02 \%$, as well as several important achievements in macroeconomic terms. and the financial sector. This shows that financial literacy and inclusion actually play an important role in maintaining economic growth in Indonesia in the midst of a slowing global economy.

This lack of evidence of the effect of financial literacy and inclusion on economic growth in Indonesia shows that efforts to increase financial literacy and inclusion in Indonesia still need to be further improved in order to achieve its main goal, namely inclusive growth. In the era of globalization and dynamic economic conditions, the Government needs to optimize all resources to encourage the public to be involved in economic development, including in the financial sector. Community involvement in the financial sector can be realized in a condition when every member of the community has access to take advantage of various formal financial services that are in accordance with their needs and abilities in order to achieve prosperity.

The findings of this study can be used by Otoritas Jasa Keuangan (OJK) as a material consideration in the preparation and improvement of policy strategies in order to increase financial literacy and inclusion as stated in the National Strategy for Financial Literacy and Inclusion. Not only for OJK, this strategy is expected to be a guide for Financial Services Businesses in preparing programs in order to increase financial literacy and inclusion.
Furthermore, the findings of this study can be used as a measuring tool to evaluate the effectiveness and efficiency of financial literacy and inclusion programs that have been jointly pursued by both the Otoritas Jasa Keuangan (OJK) and the financial services industry.

The results of this research become valuable input for OJK and Financial Services Businesses in determining educational activities and innovation of financial products or services in the midst of the financial services industry which is undergoing dynamic changes and continues to move forward.

\section{CONCLUSIONS}

Increasing financial literacy and financial inclusion has become a global issue believed to play an important role in increasing economic growth. However, the phenomenon that occurred in Indonesia, the increases in financial literacy and financial inclusion in several provinces were not followed by the economic growth of the province. Therefore, this study aims to analyze the effect of financial literacy and financial inclusion on economic growth in Indonesia. The object in this study is 34 provinces in Indonesia with 2 survey periods, 2016 and 2019. The data analysis method used is panel data regression using EViews 10 software. Chow test and Hausman test are carried out to determine the best model. The results of the hypothesis test show that financial literacy and financial inclusion have no significant effect on economic growth in Indonesia, either partially or simultaneously. This shows that efforts to increase financial literacy and inclusion in Indonesia need to be increased more in order to achieve its main goal of inclusive growth. The results of this research become valuable input for OJK and Financial Services Businesses in determining educational activities and innovation of financial products or services in the midst of the financial services industry which is undergoing dynamic changes and continues to move forward. 


\section{REFERENCES}

Bank Indonesia. (2014). Booklet Keuangan Inklusif. Jakarta: Bank Indonesia.

Beck, T., Demirguc-Kunt, A, Levine, R., (2007a). Finance, Inequality, and The Poor. Journal of Economic Growth, 12 (1), 27-49.

Bond, S. R. (2002). Dynamic Panel Data Models: A Guide to Micro Data Methods and Practice. Portuguese Economic Journal, 1, 141-162.

Demirguc-Kunt, Asli; Klapper, Leora. (2012). Measuring Financial Inclusion: The Global Findex Database (English). World Bank Policy Research Working Paper, Series 6025.

Fabya. (2011). Analisis pengaruh perkembangan sektor keuangan terhadap pertumbuhan ekonomi di Indonesia. Jurnal Ilmiah

Fakultas Ekonomi dan Manajemen. Institut Pertanian Bogor.

Falahaty, Manizheh and Hook, Law Siong. (2013). The Effect of Financial Development on Economic Growth in the MENA Region. Journal of Economic Cooperation and Development, 34 (3), 35-60.

Ghosh, S. (2011). Does financial outreach engender economic growth? Evidence from Indian states. Journal of Indian Business Research, 3 (2), 74-99.

Gul, Faid., Usman, Muhammad \& Majeed, M. Tariq. (2018). Financial Inclusion and Economic Growth: A Global Perspective. Journal of Business \& Economics, 10 (2), 133-152.

Hannig, Alfred dan Jansen, Stefan. (2010). Financial Inclusion and Financial Stability: Current Policy Issues. Asian Development Bank Institute Working Paper.

Kendall, J., Mylenko, N. and Ponce, A. (2010). Measuring financial access around the world. World Bank Policy Research Working Paper Series.

Khan, H. R. (2011). Financial Inclusion and Financial Stability: are They Two Sides of the Same Coin. The Indian Bankers Association and Indian Overseas Bank.

Kim, D.-W., Yu, J.-S., \& Hassan, M. K. (2018). Financial inclusion and economic growth in OIC countries. Research in International Business and Finance, 43, 1-14.

Law, S. H., Azman-Saini, W. N., \& Tan, H. B. (2014). Economic Globalization and Financial Development in East Asia: A Panel Cointegration and Causality Analysis. Emerging Markets Finance and Trade, 50(1), 210-225.

Manurung Jonni J., dan Adler H. Manurung, 2009. Ekonomi Keuangan dan Kebijakan Moneter. Cetakan Pertama. Jakarta: Salemba Empat.

Masoud, N. and Hardaker, G. (2012). The Impact of Financial Development on Economic Growth: Empirical Analysis of Emerging Market Countries. Studies in Economics and Finance, 29 (3), 148-173.

Martinez, M.V. (2011). The Political Economy of Increased Financial Access; A Thesis submitted to the Faculty of the Graduate School of Arts and Sciences of Georgetown University; Washington, DC.

Mihasonirina, A and Kangni, K. (2011). ICT, Financial Inclusion, and Growth: Evidence from African Countries. International Monetary Fund Working Paper WP/11/73, Washington, DC.

Naceur, S.B., and Samir G. (2007). Stock Markets, Banks, and Economic Growth: Empirical Evidence from the MENA Region. Research in International Business and Finance, 21(2), 297-315.

Otoritas Jasa Keuangan. (2014). Survei Nasional Literasi dan Inklusi Keuangan $2013 . \quad$ Diakses di https://sikapiuangmu.ojk.go.id/FrontEnd/images/Document/buku\%20statistik 2013.pdf pada tanggal 27 Mei 2021 
Otoritas Jasa Keuangan. (2017a). Survei Nasional Literasi dan Inklusi Keuangan 2016. Diakses di https://sikapiuangmu.ojk.go.id/FrontEnd/images/Document/buku\%20statistik_2016.pdf pada tanggal 27 Mei 2021

Otoritas Jasa Keuangan. (2017b). Strategi Nasional Literasi Keuangan (Revisit 2017). Diakses di https://www.ojk.go.id/id/berita-dan-kegiatan/publikasi/Documents/Pages/Strategi-Nasional-Literasi-Keuangan-Indonesia(Revisit-2017)-/SNLKI\%20(Revisit\%202017).pdf pada tanggal 27 Mei 2021.

Otoritas Jasa Keuangan. (2020). Survei Nasional Literasi dan Inklusi Keuangan 2019. Diakses di https://www.ojk.go.id/id/berita-dan-kegiatan/publikasi/Documents/Pages/Survei-Nasional-Literasi-dan-Inklusi-Keuangan-2019 pada tanggal 27 Mei 2021.

Pradhan, R.P., Arvin B. M., Norman N. R., Nair M., Hall, J.H. (2016). Insurance Penetration and Economic Growth Nexus: Cross-Country Evidence from ASEAN. Research in International Business and Finance, 36, 447-458

Sarma, M., \& Pais, J. (2011). Financial Inclusion and Development. Journal of International Development, 23(5), $613-628$.

Sarma, M. (2016). Measuring Financial Inclusion for Asian Economies. Financial Inclusion in Asia, 3-34.

Sekaran, U. (2006). Research Methods For Business (Empat). Jakarta: Salemba Empat.

Raza, M. S., Tang, J., Rubab, S., \& Wen, X. (2019). Determining the nexus between financial inclusion and economic development in Pakistan. Journal of Money Laundering Control.

Winarno, W. W. (2011). Aplikasi Ekonometrika dan Statistika dengan EViews (3rd ed.). Yogyakarta: UPP STIM YKPN.

Conflict of Interest Statement: The authors declare that the research was conducted in the absence of any commercial or financial relationships that could be construed as a potential conflict of interest.

Copyright (C) tahun terbit nama belakang and nama belakang. This is an openaccess article distributed under the terms of the Creative Commons Attribution License (CC BY). The use, distribution or reproduction in other forums is permitted, provided the original author(s) and the copyright owner(s) are credited and that the original publi-cation in this journal is cited, in accordance with accepted academic practice. No use, distribution or reproduction is permitted which does not comply with these terms. 


\section{LIST OF FIGURES}

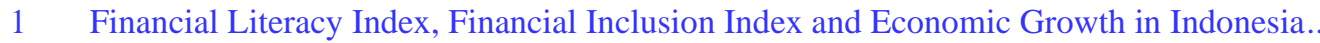




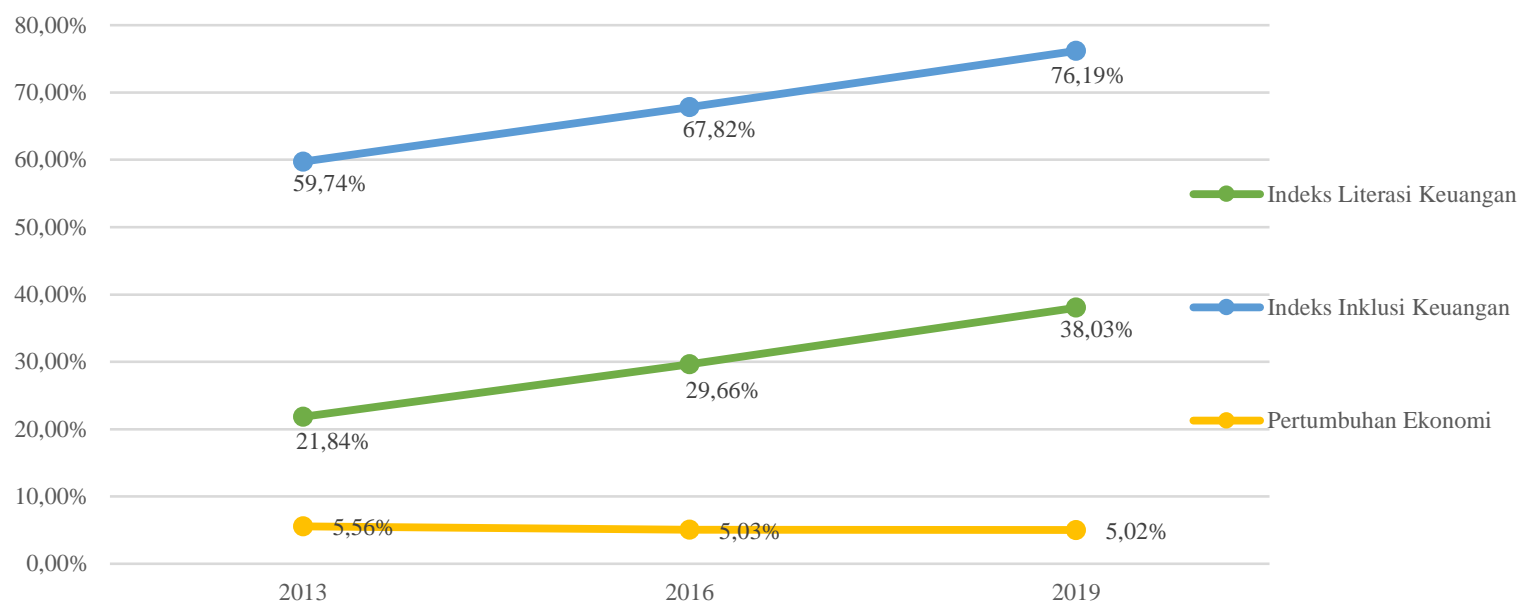

Figure 1 | Financial Literacy Index, Financial Inclusion Index and Economic Growth in Indonesia

Source: SNLIK 2016, SNLIK 2019, BPS 2020 processed in 2021 


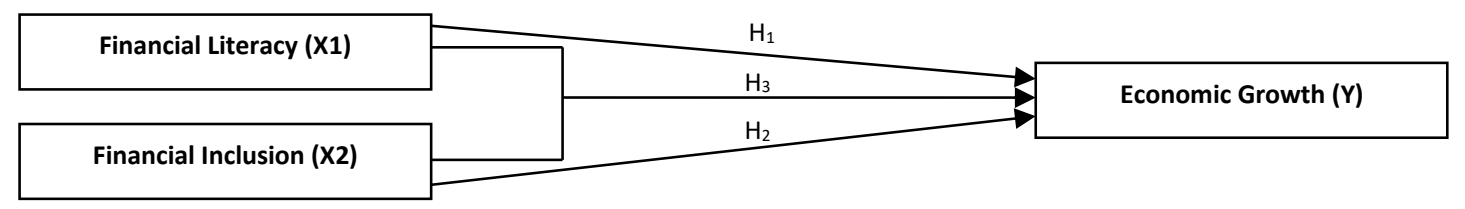

Figure $2 \mid$ Research Model

Source: Data processed by researchers, 2021 


\section{LIST OF TABLES}

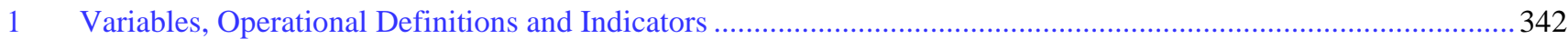

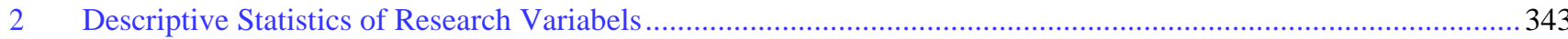

3 Financial Literacy Index, Financial Inclusion Index and Indonesia's Economic Grwoth in 2016 and 2019 ............343

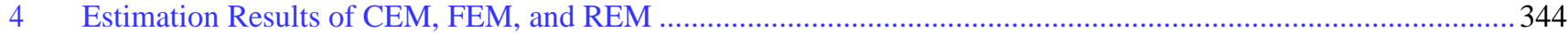

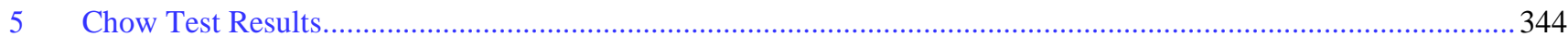

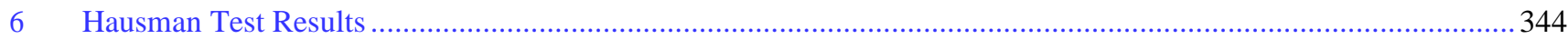

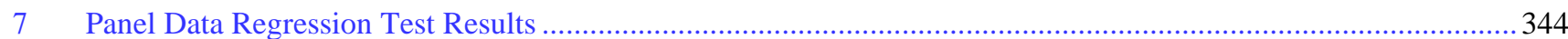


TABLE 1 | Variables, Operational Definitions and Indicators

\begin{tabular}{llc}
\hline \multicolumn{1}{c}{ Variable } & \multicolumn{1}{c}{ Operational Definitions } & Indicator \\
\hline Financial Literacy $(\mathrm{X} 1)$ & $\begin{array}{l}\text { The knowledge, beliefs and skills possessed by the } \\
\text { community that can influence the attitudes and behavior of } \\
\text { the community in improving the quality of decision making } \\
\text { and the quality of financial management so as to achieve } \\
\text { community welfare }\end{array}$ & $\begin{array}{c}\text { Financial Literacy } \\
\text { Index } \\
\text { (in } \%)\end{array}$ \\
\hline Financial Inclusion (X2) & $\begin{array}{l}\text { he availability of access to various financial institutions, } \\
\text { products, and services in accordance with the needs and } \\
\text { capabilities of the community in order to improve the welfare } \\
\text { of the community. }\end{array}$ & $\begin{array}{c}\text { Financial Inclusion } \\
\text { Index }\end{array}$ \\
(in $\%)$ \\
\hline Economic Growth (Y) & $\begin{array}{l}\text { An increase in the production capacity of an economy } \\
\text { embodied in national income. }\end{array}$ & GDP per capita growth \\
(in \%)
\end{tabular}

Source: Data processed by researchers, 2021 
TABLE 2 | Descriptive Statistics of Research Variabels

\begin{tabular}{cccccc}
\hline & N & Minimun & Maksimum & Mean & Std. Deviation \\
\hline Economic Growth (Y) & 68 & $-15.7 \%$ & $9.9 \%$ & $5.0 \%$ & 0.0303 \\
\hline Financial Literacy (X1) & 68 & $19.3 \%$ & $59.2 \%$ & $33.9 \%$ & 0.0767 \\
\hline Financial Inclusion (X2) & 68 & $58.6 \%$ & $94.8 \%$ & $72.1 \%$ & 0.1005
\end{tabular}

Source: Data processed by researchers, 2021 
TABLE 3 | Financial Literacy Index, Financial Inclusion Index and Indonesia's Economic Grwoth in 2016 and 2019

\begin{tabular}{|c|c|c|c|c|c|c|}
\hline \multirow{2}{*}{ Provinces } & \multicolumn{2}{|c|}{$\begin{array}{c}\text { Financial Literacy } \\
\text { Index }\end{array}$} & \multicolumn{2}{|c|}{$\begin{array}{c}\text { Financial Inclusion } \\
\text { Index }\end{array}$} & \multicolumn{2}{|c|}{$\begin{array}{l}\text { Economic } \\
\text { Growth }\end{array}$} \\
\hline & 2016 & 2019 & 2016 & 2019 & 2016 & 2019 \\
\hline Aceh & $32.73 \%$ & $44.36 \%$ & $73.09 \%$ & $86.09 \%$ & $3.3 \%$ & $4.1 \%$ \\
\hline Sumatera Utara & $32.36 \%$ & $37.96 \%$ & $75.27 \%$ & $93.98 \%$ & $5.2 \%$ & $5.2 \%$ \\
\hline Sumatera Barat & $27.27 \%$ & $34.55 \%$ & $66.91 \%$ & $66.75 \%$ & $5.3 \%$ & $5.1 \%$ \\
\hline Riau & $29.46 \%$ & $43.19 \%$ & $69.45 \%$ & $86.39 \%$ & $2.2 \%$ & $2.8 \%$ \\
\hline Jambi & $26.91 \%$ & $35.17 \%$ & $66.91 \%$ & $64.83 \%$ & $4.4 \%$ & $4.4 \%$ \\
\hline Sumatera Selatan & $31.27 \%$ & $40.05 \%$ & $72.36 \%$ & $85.08 \%$ & $5.0 \%$ & $5.7 \%$ \\
\hline Bengkulu & $27.64 \%$ & $34.12 \%$ & $67.27 \%$ & $85.56 \%$ & $5.3 \%$ & $5.0 \%$ \\
\hline Bangka Belitung & $29.45 \%$ & $30.97 \%$ & $69.09 \%$ & $61.94 \%$ & $5.1 \%$ & $5.3 \%$ \\
\hline Lampung & $26.91 \%$ & $35.70 \%$ & $69.82 \%$ & $64.57 \%$ & $4.1 \%$ & $3.3 \%$ \\
\hline Kep. Riau & $37.09 \%$ & $45.67 \%$ & $74.55 \%$ & $92.13 \%$ & $5.0 \%$ & $4.9 \%$ \\
\hline DKI Jakarta & $40.00 \%$ & $59.16 \%$ & $78.18 \%$ & $94.76 \%$ & $5.9 \%$ & $5.9 \%$ \\
\hline Jawa Barat & $38.70 \%$ & $37.43 \%$ & $68.31 \%$ & $88.48 \%$ & $5.7 \%$ & $5.1 \%$ \\
\hline Jawa Tengah & $33.51 \%$ & $47.38 \%$ & $66.23 \%$ & $65.71 \%$ & $5.2 \%$ & $5.4 \%$ \\
\hline DIY & $38.55 \%$ & $58.53 \%$ & $76.73 \%$ & $76.12 \%$ & $5.0 \%$ & $6.6 \%$ \\
\hline Jawa Timur & $35.58 \%$ & $48.95 \%$ & $73.25 \%$ & $87.96 \%$ & $5.6 \%$ & $5.5 \%$ \\
\hline Banten & $38.18 \%$ & $39.27 \%$ & $69.45 \%$ & $84.29 \%$ & $5.3 \%$ & $5.5 \%$ \\
\hline Bali & $37.45 \%$ & $38.06 \%$ & $76.00 \%$ & $92.91 \%$ & $6.3 \%$ & $5.6 \%$ \\
\hline NTB & $21.45 \%$ & $34.65 \%$ & $63.27 \%$ & $62.73 \%$ & $5.8 \%$ & $4.0 \%$ \\
\hline NTT & $28.00 \%$ & $27.82 \%$ & $62.18 \%$ & $60.63 \%$ & $5.1 \%$ & $5.2 \%$ \\
\hline Kalimantan Barat & $30.55 \%$ & $36.48 \%$ & $65.45 \%$ & $75.35 \%$ & $5.2 \%$ & $5.0 \%$ \\
\hline Kalimantan Tengah & $26.18 \%$ & $37.01 \%$ & $60.36 \%$ & $74.80 \%$ & $6.3 \%$ & $6.2 \%$ \\
\hline Kalimantan Selatan & $23.27 \%$ & $36.22 \%$ & $59.27 \%$ & $74.54 \%$ & $4.4 \%$ & $4.1 \%$ \\
\hline Kalimantan Timur & $30.55 \%$ & $39.63 \%$ & $74.91 \%$ & $92.39 \%$ & $-0.4 \%$ & $4.8 \%$ \\
\hline Kalimantan Utara & $26.55 \%$ & $35.43 \%$ & $61.45 \%$ & $65.09 \%$ & $3.6 \%$ & $6.9 \%$ \\
\hline Sulawesi Utara & $28.73 \%$ & $38.85 \%$ & $68.36 \%$ & $83.99 \%$ & $6.2 \%$ & $5.7 \%$ \\
\hline Sulawesi Tengah & $22.55 \%$ & $39.63 \%$ & $65.09 \%$ & $84.51 \%$ & $9.9 \%$ & $7.2 \%$ \\
\hline Sulawesi Selatan & $28.36 \%$ & $32.46 \%$ & $68.00 \%$ & $86.91 \%$ & $7.4 \%$ & $6.9 \%$ \\
\hline Sulawesi Tenggara & $26.55 \%$ & $36.75 \%$ & $66.91 \%$ & $75.07 \%$ & $6.5 \%$ & $6.5 \%$ \\
\hline Gorontalo & $23.27 \%$ & $31.23 \%$ & $62.55 \%$ & $60.89 \%$ & $6.5 \%$ & $6.4 \%$ \\
\hline Sulawesi Barat & $26.91 \%$ & $34.91 \%$ & $65.45 \%$ & $62.99 \%$ & $6.0 \%$ & $5.7 \%$ \\
\hline
\end{tabular}




\begin{tabular}{lcccccc}
\hline Maluku & $26.18 \%$ & $36.48 \%$ & $64.00 \%$ & $65.62 \%$ & $5.7 \%$ & $5.6 \%$ \\
\hline Maluku Utara & $27.27 \%$ & $37.53 \%$ & $64.00 \%$ & $75.85 \%$ & $5.8 \%$ & $6.1 \%$ \\
\hline Papua Barat & $19.27 \%$ & $28.87 \%$ & $58.55 \%$ & $59.84 \%$ & $4.5 \%$ & $2.7 \%$ \\
\hline Papua & $22.18 \%$ & $29.13 \%$ & $61.45 \%$ & $60.89 \%$ & $9.1 \%$ & $-15.7 \%$ \\
\hline
\end{tabular}

Source: Data processed by researchers, 2021 
TABLE 4 | Estimation Results of CEM, FEM, and REM

\begin{tabular}{|c|c|c|c|c|c|c|}
\hline \multirow{2}{*}{ Variabel } & \multicolumn{2}{|c|}{$\begin{array}{c}\text { Common Effect } \\
\text { Model }\end{array}$} & \multicolumn{2}{|c|}{$\begin{array}{l}\text { Fixed Effect } \\
\text { Model }\end{array}$} & \multicolumn{2}{|c|}{$\begin{array}{c}\text { Random Effect } \\
\text { Model }\end{array}$} \\
\hline & $\begin{array}{l}\text { t- } \\
\text { Stat }\end{array}$ & Prob. & t-Stat & Prob. & t-Stat & Prob. \\
\hline Financial Literacy & $\begin{array}{c}- \\
0.342\end{array}$ & 0.733 & 0.128 & 0.899 & $\begin{array}{c}- \\
0.044\end{array}$ & 0.965 \\
\hline $\begin{array}{l}\text { Financial } \\
\text { Inclusion }\end{array}$ & 0.483 & 0.631 & $\begin{array}{c}- \\
0.768\end{array}$ & 0.448 & $\begin{array}{c}- \\
0.319\end{array}$ & 0.751 \\
\hline
\end{tabular}

Source: Data processed by researchers, 2021 
TABLE 5 / Chow Test Results

\begin{tabular}{lccc}
\hline \multicolumn{1}{c}{ Effects Test } & Statistic & d.f. & Prob. \\
\hline Cross-section F & 4.836825 & $(31,30)$ & 0.0000 \\
\hline Cross-section Chi-square & 114.651826 & 31 & 0.0000
\end{tabular}

Source: Data processed by researchers, 2021 
TABLE 6 / Hausman Test Results

\begin{tabular}{cccc}
\hline Test Summary & Chi-Sq. Statistic & Chi-Sq. d.f. & Prob. \\
\hline Cross-section random & 1.202545 & 2 & 0.5481
\end{tabular}

Source: Data processed by researchers, 2021 
TABLE 7 / Panel Data Regression Test Results

\begin{tabular}{cccccr}
\hline Variable & Coefficient & $\begin{array}{c}\text { Std. } \\
\text { Error }\end{array}$ & $\begin{array}{c}\text { t- } \\
\text { Statistic }\end{array}$ & Prob. & Note \\
\hline Konstanta (C) & 0.057584 & 0.009369 & 6.146316 & 0.0000 & Significant \\
& & & & & \\
\hline Literasi Keuangan & -0.000893 & 0.020126 & - & 0.9647 & Not \\
(X1) & & & 0.044393 & & significant \\
\hline Inklusi Keuangan & -0.005242 & 0.016437 & -0.7509 & Not \\
(X2) & & & 0.318927 & & \\
\hline R-squared & & 0.003399 & & \\
F-statistic & & 0.104018 & \\
Prob (F-statistic) & & 0.901369 & Tidak \\
& & Signifikan &
\end{tabular}

Source: Data processed by researchers, 2021 